\title{
WestVirginiaUniversity
}

THE RESEARCH REPOSITORY @ WVU

Graduate Theses, Dissertations, and Problem Reports

2004

\section{Women and social services in Saudi Arabia}

\author{
Khadija Nasseef \\ West Virginia University
}

Follow this and additional works at: https://researchrepository.wvu.edu/etd

\section{Recommended Citation}

Nasseef, Khadija, "Women and social services in Saudi Arabia" (2004). Graduate Theses, Dissertations, and Problem Reports. 830.

https://researchrepository.wvu.edu/etd/830

This Thesis is protected by copyright and/or related rights. It has been brought to you by the The Research Repository @ WVU with permission from the rights-holder(s). You are free to use this Thesis in any way that is permitted by the copyright and related rights legislation that applies to your use. For other uses you must obtain permission from the rights-holder(s) directly, unless additional rights are indicated by a Creative Commons license in the record and/ or on the work itself. This Thesis has been accepted for inclusion in WVU Graduate Theses, Dissertations, and Problem Reports collection by an authorized administrator of The Research Repository @ WVU. For more information, please contact researchrepository@mail.wvu.edu. 


\title{
Women and Social Services in Saudi Arabia
}

\author{
Khadija Nasseef
}

\author{
Thesis submitted to the \\ College of Arts and Sciences \\ at West Virginia University \\ in partial fulfilment of the requirements
}

for the degree of

\author{
Master of Arts \\ in \\ Sociology
}
Lawrence Nichols, Ph.D., Chair
Roland Althouse, Ph.D.
Neal Newfield, Ph.D.

Department of Sociology and Anthropology

\author{
Morgantown, West Virginia \\ 2004
}

Keywords: Social Services, Women, Saudi Arabia

Copyright 2004 Khadija Nasseef 


\section{ABSTRACT \\ Women and Social Services in Saudi Arabia}

\section{Khadija Nasseef}

This master thesis talks about social services for women that provided by social welfare agencies in Saudi Arabia. This thesis is a descriptive study that uses the content analysis as a method to investigate social services agencies that provides special services for women. This thesis also had special interest in social services that improve women's lives in Saudi Arabia. The content analysis is made on documents and brochures of 4 main social services agencies that offer services for women. The content analysis was made in term of these agencies main aim and target, their main massage, their programs for women, and their statistics. The main questions this thesis tried to answer is what kind of social services welfare agencies offering for women? How do they describe women in their documents? And how they differ from each other? 


\section{Acknowledgments}

I would like to thank my committee chairman, Dr. Lawrence Nichols, for his hard work in advising and supporting me throughout this thesis. Special thanks also to my

committee member, Dr. Roland Althouse, for his support throughout my Master's study and this thesis. I would also like to thank my thesis committee member Dr. Neal Newfield, for his appreciation, interest, and assistance in this thesis.

I would like to dedicate this work to my mother Hind, my father Abdullah, and my husband Ahmed Binmahfoodh, for their endless support throughout my study. I would also like to give special recognition to my grandmother Sadekha, for inspiring me in so many ways. 


\section{Table Contents}

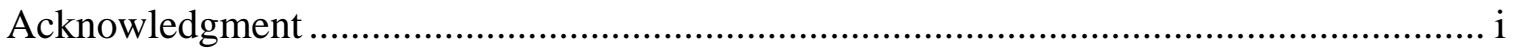

Table of Contents ...................................................................................................... ii

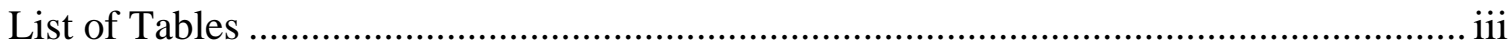

Chapter One - Women and Social Services in Saudi Arabia ......................................1

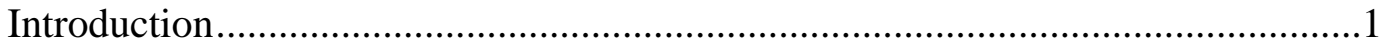

General Information About Saudi Arabia.........................................................

Background Information....................................................................................

Future and Challenges.............................................................................................

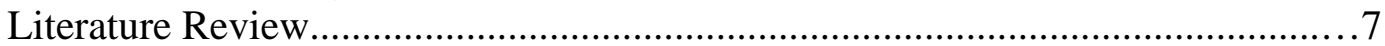

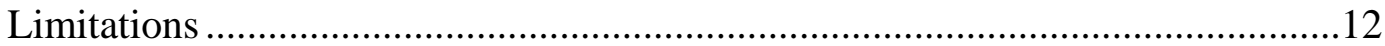



Sample and Procedure.......................................................................................13

Content Analysis ...............................................................................................14

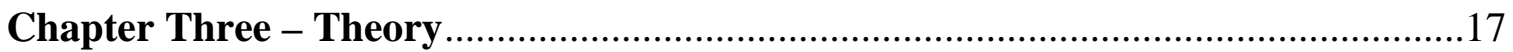

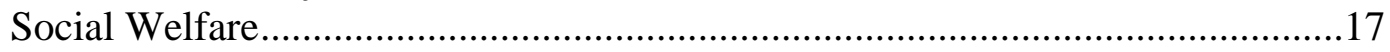

Social Development Approach ..........................................................................17

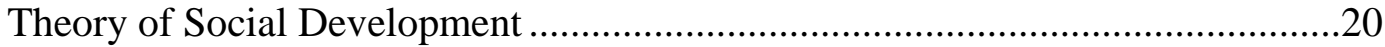

Developing Countries ........................................................................................21

Social Welfare in Developing Countries ........................................................22

Gender Empowerment Approach .................................................................23

The Development of Women's Organizations in the Middle East .........................24

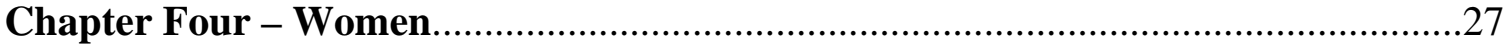

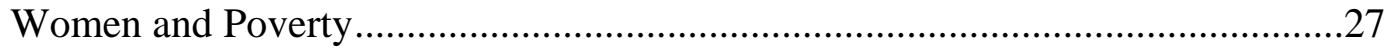

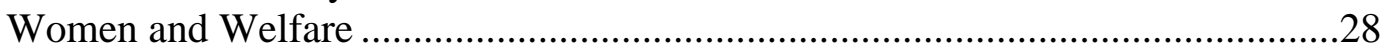

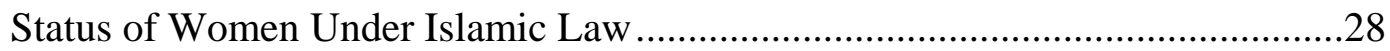

Women in Saudi Arabia..................................................................................29



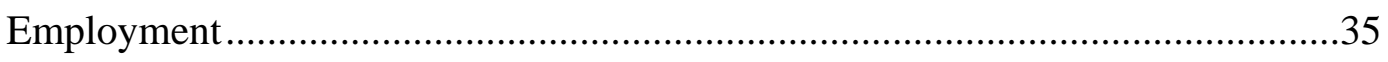

Chapter Five - Social Services in Saudi Arabia ........................................................39

History of Social Work in Saudi Arabia ...............................................................39

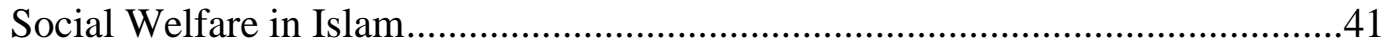

Ministry of Social Affairs in Saudi Arabia ...........................................................4

Community Services ................................................................................42 
Role of Social Workers in Community Development Centers ......43

Agency of Social Affairs .....................................................................45

Training and Research Center..................................................46

Women's Supervision Offices ....................................................46

General Administration for Rehabilitation .................................47

General Administration for Care and Social Guidance ................47

General Administration for Social Correction..............................48

Social Research Center .............................................................49

General Administration for Private Institutes and Associations....49

General Administration for Social Development .........................50

Content Analyses of Social Services Associations ............................................51

Ministry Agency of Social Affairs........................................................53

Manifest Analysis of Social Affairs Agency ................................53

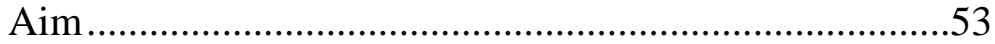

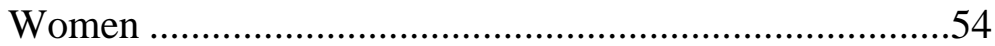

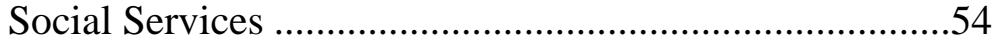



Women's Welfare Society ...............................................................55

Manifest Analysis of Women's Welfare Society..........................56

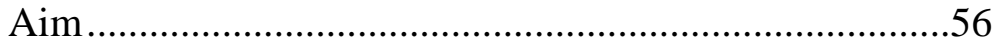

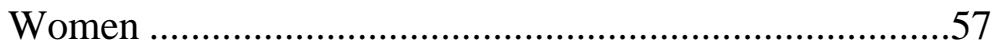

Social Services ....................................................57

Personal Influence ....................................................58

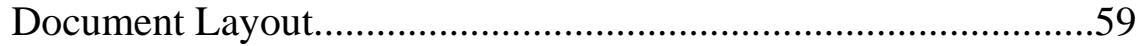

Alfaisaliha Women's Charity Association..............................................60

Manifest Analysis of Alfaisaliha Women's Charity Association ..61



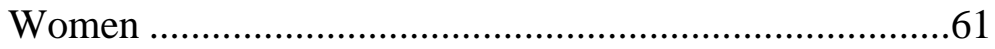

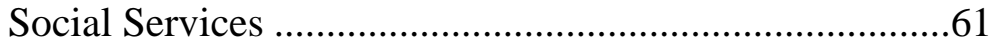

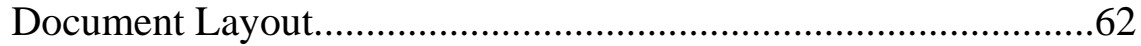



Manifest Analysis of Albir Association......................................63

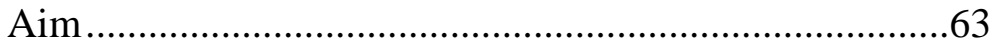



Social Services ........................................................64

Document Layout..............................................................64

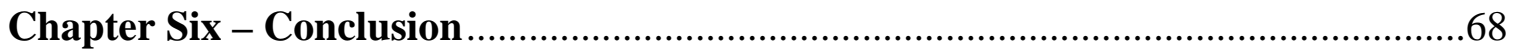






\section{List of Tables}

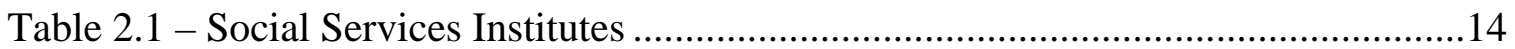

Table 5.1 - The Development of the Charity Associations' Programs ............................50

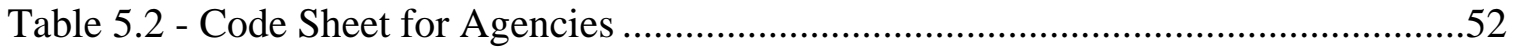

Table 5.3 - Summary of the Content Analyses for the Four Associations........................65 


\section{Chapter One}

\section{Women and Social Services in Saudi Arabia}

\section{Introduction}

Saudi Arabian society has been experiencing great change, and in all aspects of life. In the last few decades after the discovery of oil in Saudi Arabia, and the economic boom in the 1970s, dramatic changes have taken place. Most industrial countries took centuries to establish modern societies, but the same foundational necessities were available to Saudi society in just a few decades. With the timely discovery of oil in Saudi Arabia, material and economic development happened in no time. Naturally however, social and cultural development has taken more time, as people have had to adjust to the dramatic material changes that have taken place. Many new fields have been introduced and new jobs have been created, which has turned the simple life into a more complicated, professional one.

In the beginning, men were the main labor force - this as a natural result of tradition. As more demands were forced onto the society, there was a greater need to use the other half of the population to participate in the development process. As girls' education spread in every region, new generations of educated women were ready to work. As a result, policy makers started to include women in their plans for development. Still, changes regarding the status of women have moved very slowly compared with other Arab countries in the area.

In recent years, the focus has been switched to Saudi women as one of the most changing elements of the society, with growing interest in integrating women in the developmental process (AlMunajjed 1996). According to Abdulaziz Al-hazzaa 
(1993), studies have indicated that economic development planners have neglected the role of women. Recently however, Saudi officials and development planners have focused their efforts to mobilize women's power to achieve development goals. In fact, the Saudi government has been struggling to balance between developmental demands and the conservative tradition that often opposes change. As society has become more complex, there has been an urgent need to establish separate institutes for women to respond to their needs. Because of the segregation between men and women, separate institutes have always been common, every public institution with two buildings - one for men and one for women. Inside women's buildings, women do not wear scarves on their heads. In fact, they display modern habits and dress, wearing make-up, and expensive or fashionable clothing. They do not display the same modesty amongst each other as amongst men. However, in places such as hospitals, where women and men work together, traditional modesty is expected of the women.

In Saudi Arabia, the traditional role of the male has been as the financial support of the family; especially for female members of the family. However, as life's demands have taken over and the attitudes toward women's work and education have changed, many husbands have accepted the financial participation of the wife in supporting the family. In fact, many husbands now look for wives that are more equally qualified in educational and job skills. Still, there are some men who do not admit their wives' financial participation in the family. However, there is no doubt there has been a change in the attitudes concerning women as financial supporters.

Many women in Saudi Arabia still completely rely on men for financial support. In fact, if they lose the male supporter, they might face starvation, because a lack of education makes them vulnerable in a more competitive job market. There are in fact, 
a large number of disadvantaged women that seek welfare assistance, many needing complete assistance. A new approach to social services in Saudi Arabia provides developmental services for these women, not just to help them immediately, but to improve their lives. Improving the lives of women means making them part of the development process of the society, and giving them the essential tools to build a successful life. Women's welfare associations have been established as a result of the demands of the society and the need to create professional institutes that respond to the developing state. In other words, instead of relying on the family and tribal support for help, more and more professional institutes offer services that complement the changing society.

This research is intended to be a descriptive study of existing social services in Saudi Arabia. The purpose of the content analysis is to examine the changing needs of women in Saudi Arabia. The analysis will also investigate the availability of social programs in Saudi Arabia that aim to promote the general welfare of women. This new trend, to include the women as participants in the country’s social development, will be examined through the content analysis of a number of social services agencies that have specialized in assistance to women in Saudi Arabia. Specialized social services for women are to be used as an indicator for the recognition of women's needs by Saudi officials and development planners. The independent variable (social development services) will be generally defined as the educational and training programs that aim to promote the quality of women's welfare within the social services centers. The dependent variable (women) will be generally defined as poor women without a male or other financial supporter within the family, who seek welfare benefits. 


\section{General Information About Saudi Arabia}

Attention has been drawn to Saudi Arabia in the last few decades for several reasons. First, Saudi Arabia has become a major influence as the world's largest exporter and producer of petroleum. It is also the world's richest in its reserves of oil. Finally, the presence of the two holy cities Meccah and Medinah, have made Saudi Arabia a place for millions of Muslims to gather, pray, and make their pilgrimage around the year (AlMunajjed 1997). Attention has come not only from the west, but also from the Islamic world, as there are many expectations of Saudi Arabia. Due to such high expectations, Saudi Arabia sometimes faces opposing constraints that have to be dealt with by maintaining a balanced relationship with the world's countries.

\section{Background Information}

In 1902, Abd Al-Aziz bin Abd al-Rahman Al Saud captured Riyadh, and 30 years later, the Arabian Peninsula was unified under one country (Royal Embassy of Saudi Arabia in Washington D.C., http://www.saudiembassy.net/). In the 1930s, the discovery of oil transformed the country.

Saudi Arabia occupies $80 \%$ of the Arabian Peninsula in the southeastern part of Asia, with a total area of about 2,250,000 square kilometers (868,730 square miles). The population of about 24,293,844 includes 5,576,076 non-nationals (CIA World Fact Book, July 2003 est. ). The first language is Arabic, and Islam is its

religion. The capital of Saudi Arabia is Riyadh, and King Fahd bin Abdul Aziz is Prime Minister and Custodian of The Two Holy Mosques. The main Administrative Regions are Al-Baha, Al-Jouf, Asir, Eastern, Hail, Jizan, Madinah, Makkah, Najran, Northern Border, Qasim, Riyadh, and Tabouk. The Saudi Ministry of Culture \& Information web site suggested that in order to understand the history of Saudi Arabia 
and its political, economic, and social development, it is necessary to realize that Islam, which permeates every aspect of a Muslim's life, also permeates every aspect

of the Saudi Arabian state. It is not only the Islamic religion, but also cultural tradition, which affects people at the societal level.

Education has been one of the most important concerns to Saudi Arabian government. However, the government has had to take into account both religion and traditions as changes have taken place. To ensure that the Saudi population is ready for the challenges posed by the developmental process, the government has committed vast resources to a program covering primary, secondary and higher levels of education. All the development plans have taken into account the educational aspirations of the Saudi people, providing free education to all. The educational system has been continuously and systematically expanded to accommodate the evergrowing demand for educational services. Through this investment, Saudi Arabia has been attempting to guarantee an equality of opportunity for all, and to ensure that the country's need for an educated and trained national workforce to carry forward the country's future development, can be fulfilled. (Saudi Ministry of Culture \& Information, (http://www.saudinf.com/)).

\section{Future and Challenges}

Over recent years, the Kingdom of Saudi Arabia has been confronted with what many consider its greatest challenge: achieving modernity without surrendering its heritage, faith, or culture. Examining the statistics of the Kingdom, from GDP to literacy rates, one finds consistent success. Seventy-five years ago, Saudi Arabia did 
not exist. Today, it is a nation marked by sophisticated political, legal, and financial systems, with a culture rich in history and deep in faith.

But there is still much to be done. Since the tragedy of September 11, 2001, when the world was thrown into instability, Saudi Arabia has recognized the need for greater reform - economic, social, and political. As such, the Kingdom of Saudi Arabia has embarked upon a comprehensive reform agenda to promote a vibrant economy, a civil society, and broader political participation by Saudi citizens. In addition, Saudi Arabia has amplified its efforts to reveal its domestic progress to the international community, so that mutual understanding between the Kingdom and the nations of the world can be achieved. (Royal Embassy of Saudi Arabia in Washington D.C., ( http://www.saudiembassy.net/)).

According to the Library of Congress Country Studies (2004), Saudi tribal allegiance and the Bedouin heritage have been weakened since the mid-twentieth century by the increased role of a centralized state, by the growth of urbanization, and by the industrialization that has accompanied the discovery of oil. At the same time, the impact of Islam on different elements of the population has varied. Many of the educated, younger technocrats have felt a need to adapt Islamic institutions to fit the demands of modern technology. Other young people, more conservatively inclined, as well as a number of their elders and those with a more traditional Bedouin life-style, still want to maintain their authority and their agenda by denying modernity and rejecting change. The government found itself caught between these two trends. On one hand, it feared the extremism of some of the traditionalists, which could well undermine the economic, educational, and social development programs that the government had been implementing, and which also constituted a threat to internal security. On the other hand, as guardian of the holy places of Islam, the sites for the 
annual pilgrimage for Muslims the world over, the government needed to legitimize itself as an "Islamic government." (LCCS, ( $\underline{\text { http://lcweb2.loc.gov/cgi- }}$ bin/query/r?frd/cstdy:@field(DOCID+sa0011)). For women, social change has also meant being caught between such progressive and traditional thinking. As a result of this position, women have learned to maintain a delicate balance between tradition and progressive action.

\section{Literature Review}

Yousef Uthaimeen (1986) conducted a PhD dissertation on the welfare state in Saudi Arabia as an attempt to explain and analyse the emergence and expansion of the welfare state in Saudi Arabia. This study is an analysis of quantitative data provided by the government. The historical works done by native and foreign historians, and the academic statements, comments, and works of contemporary Middle Eastern scholars are drawn upon. More importantly, the author analysed the context of theoretical categories put fourth by the Political Budget Model as an approach to understanding the welfare state in Saudi Arabia. In fact, this study explores in some detail, the welfare state's origin, structure, dynamics, organization, finance, function, and transformation over a period of time.

This study concluded that the ideas explained by the conventional approaches to the welfare state are of little value in understanding the welfare state phenomenon in Saudi Arabia. The author sees a more useful approach is to analyse the welfare state in terms of important issues which faced the state in the last fifty years that include: integrating by pulling together various independent tribal grouping under one nation and maintenance of social stability. Uthaimeen argue that welfare programs leads to social stability through managing different problems may face the state. 
Instability existed because of the conflict between tribes along with the lack of modern institutions. This can be related to this study by using it in understanding that the establishment of Saudi modern state went through many obstacles among them are unifying different tribes and cultures under one nation. Women were one of the issues that those different people have different opinions about.

Al-hazzaa (1993) conducted a Ph.D dissertation which attempted to anticipate future changes in the conservative cultural attitudes toward women as a result of education, urbanization, and economic modernization, which have been taking place in the last two decades. This study also tried to project the future educational and training programs, and possible employment opportunities for women. In addition, Al-hazzaa investigated possible government policies and legislation that would be needed for the participation of women in the labor force. The author used two methods in this study. First, the author conducted Ethnographic Future Research (EFR) interviews with a panel of “experts” consisting of 25 panellists. Second, using the survey method, the author developed a questionnaire based on the information gathered from the interviews. According to the author: " Summaries from the interviews were sorted out in the form of 107 future trends for the questionnaire. The questionnaire was administered to a panel of 172 experts and they were asked to indicate the desirability and probability of each trend by using five-point scales” (Alhazzaa 1993:15).

The results show that the projection calls for more change than persistence. Employment projections call for more participation of women especially in education, health (doctors, nurses, and social workers), and social affairs. For example, teaching in schools, collages and universities is the most popular field that attract women. 
This study found that women would be somewhat trapped in the process of preserving the authenticity of culture. In education, most women would be in schools and universities, but they would lack the educational opportunities in the fields of advanced science, technology and law. In doing this thesis on women this study is important in understanding the past, present and future of women in Saudi Arabia.

Mona AlMunajjed (1997) provides a description of women in Saudi Arabia, from their status to education and work. The main purpose of the book is to examine the quality of Saudi women's lives within the changing society, and the roles and contributions of women to the development of their country. The author conducted interviews with 100 Saudi women, dividing the women into 2 groups and categorizing the women according to their level of education and employment.

Women that were interviewed vary in their opinions about work and education and the author presented their opinions throughout the book. Their opinions were not analyzed or gathered together to draw a conclusion from. Some of them support work for women and some of them prefer being home wife, but all of them agree on the importance of education even for those who are not educated. This book makes a good resource for understanding different issues on women in Saudi Arabia.

Almaghlooth (1992) conducted a study that showed how social workers “develop their skills, update their knowledge and increase their efficiency” (5). The author discussed three objectives: the role of community development practice in Saudi Arabia, factors which influence the implementation of community development practice, and approaches that are used to meet community and social workers' needs. Almaghlooth used different methods to conduct this study, including interviewing a sample of 40 practitioners. Semi-structured interviews were used for data collection. 
This sample was drawn from 8 stratified and randomly chosen community development centers out of 22. The author also analyzed data using frequency and content analysis, and conducted a survey of related literature on community development before going into the field.

This study found that there are several factors which affect the efficiency of social workers: lack of support, limited training programs, lack of social awareness, weak understanding of the role of social work, and lack of incentives. The study also designed a 12-step program for professional social workers to build knowledge, skills, and efficiency.

Khalid Bargawi (2002) examined the education of professional staff members employed to practice social work in community development centers. According to Bargawi, this study “describes and compares the approaches, models, techniques, preferred skills, and activities utilized by social work-educated and social non-social work-educated professionals ( 7).” The study focused on five regions of Saudi Arabia: Central, Western, Eastern, Northern, and Southern. A self-administered questionnaire was distributed to 106 employed staff members from 24 centers, to examine their perceptions of social work and community development.

Bargawi’s study found that only 19 staff members have social work degrees, and 87 have degrees unrelated to social work. The study found however, that similarities exist between social work-educated and non-social work-educated staff members in terms of skill, activity, and practice within the field. It found no significant difference between their models of social work intervention, primary information-gathering methods, or their approach to community development. One of the limitations the author had mentioned is that meaning might be lost in translating the questionnaire from English to Arabic, for the purpose of being able to communicate with 
participants, and translating the open-ended answers from Arabic into English. Providing this study in this literature review might help in understanding the social services center and to see an example for such centers.

Saleh Alsoghair (1995) authored a PhD dissertation about citizen participation within rural community development centers in Saudi Arabia. The author identified three objectives of the study. First, the author examined the effects of age, marital status, education, family income, family size, residents' distance from the location of the community center, relationship with the center's workers, recognition, and citizens' acceptance of different kinds of programs in community development centers in Saudi Arabia. Second, the author examined the importance of citizens' participation in the community development process. Third, the author identified some techniques for including Saudi citizens' in the community development process.

The author conducted a survey and structured interviews to collect the data. A random sample was compiled of 350 heads of household, selected from 4,843 of the same in the Dilam area, who were served by a community development center. This study found that receiving recognition was the most important predictor of the level of participation. The findings also identified advisory committees as the most appropriate method for including citizens' input in the community development process.

Midgley’s book discusses international social welfare as it relates to the globalization of modern society. The author provides whole sections about existing international social welfare and challenges arising from it, international social development, and the activities and collaborative efforts of international agencies. It also focuses on issues of comparative social policy, describing welfare provisions in different countries, and examines theoretical debate at the international level (1995). 
Midgely (1995) also provided a section about promoting the well-Being of women. He explained that many international activities are concerned with organizing and empowering women by improving their welfare and recognizing their own rights. Women's organizations are created form community groups of women who are usually educated middle class women. Those women seek to advocate on behalf of women issues and may engaged in the delivery of services. In relation to this study Midgely section about women can support the argument of improving women lives through social welfare.

In conclusion, based on this literature review I would anticipate that many of the above mentioned literature would support my findings. This literature will provide the foundation of my thesis. Each resource will support different part of this thesis. 


\section{Chapter Two \\ Research Methodology}

\section{Sample and Procedure}

This research describes social services that exist for women in Saudi Arabia.

Research samples were drawn from Jeddah city in Saudi Arabia for several reasons.

First of all the author from Jeddah, and am interested in knowing more about it.

Second, conducting this research in a familiar setting allows the author to understand and explain it better. In addition, the author is planning to go back and apply the research in the future to the real sitting. The sample included four major social welfare institutes in Jeddah that specialize in, or have special sections devoted to women.

The author was interested in doing my research on women. One time when the author visited home, my father told me of an idea to establish a rehabilitation center serving only poor, single, divorced, or widowed women. This center planned to take each woman and train her according to her abilities, and provide her with job opportunities. The author really liked the idea, but because the center is currently under development it could not be include it in my research.

As I was deciding on my topic, I was also determining the appropriate and available methods to goes with the topic. My first thoughts were to do interviews and surveys in Saudi Arabia. But because of ethical and technical issues, it was almost impossible to achieve. At that time I had collected a sufficient amount of data and a number of materials on the 4 social welfare centers that I intended to study. Then I decided to make a content analysis on these materials. 
This study focuses on 4 major social services organizations that have specialized in serving women or have specialized sections providing social services to women, (illustrated in table 2.1). All these institutions are located in the city of Jeddah, which is the commercial capital in the western region of Saudi Arabia, and on the Red Sea. First I have provided a summary of each association, and then I have included more specific information from the available documents according to the codes provided. The documents I have gathered from these institutions include annual reports, brochures, and monthly publications.

Table 2.1- Social Services Institutes

\begin{tabular}{|l|l|l|}
\hline Name of Institute & Type of Institute & Main Target \\
\hline 1- Social Affairs Agency / & government/ non- & women \\
women section & profit & \\
\hline 2- Women's Welfare Society & private/ non-profit & women \\
\hline 3- Alfiasalia women association & private/ non-profit & women/ children \\
\hline 4- Albir Association & private/ non-profit & women/ children \\
\hline
\end{tabular}

The content analyses include two types. Conceptual analysis, called manifest coding, counts the presence and frequency of certain words or phrases from apparent and visible content. Semantic content analysis focuses on the overall impression and layout of the material, and how it could affect readers (Thomas and Smith 2003). 


\section{Content Analysis}

Content analysis is a method of analyzing written documents by transforming non-quantitative data into quantitative data, by counting and categorizing specific variables within the data (Johnson, Rettig, Scott, and Garrison 2002). Content analysis offers several advantages, according to the writing center in the Colorado State University web site

(http://writing.colostate.edu/references/research/content/index.cfm) The content analysis:

- can allow for both quantitative and qualitative operations

- can provide valuable historical/cultural insight over time through analysis of texts

- allows a closeness to the text which can alternate between specific categories and relationships, and also statistically analyzes the coded form of the text

- can be used to interpret texts for purposes such as the development of expert systems (since knowledge and rules can both be coded in terms of explicit statements about the relationships among concepts)

- $\quad$ is an unobtrusive means of analyzing interactions

- provides insight into complex models of human thought and language use

Content analysis suffers from several disadvantages, both theoretical and procedural. In particular, content analysis:

- can be extremely time consuming 
- is subject to increased error, particularly when relational analysis is used to attain a higher level of interpretation

- is often devoid of theoretical base, or attempts too liberally to draw meaningful inferences about the relationships and impacts implied in a study

- is inherently reductive, particularly when dealing with complex texts

- tends too often to simply consist of word counts

- often disregards the context that produced the text, as well as the state of things after the text is produced

- can be difficult to automate or computerize

\section{Limitations}

- My main limitation has been the inability to apply my study, and to personally interact with social services recipients, so their perspectives cannot be properly represented.

-Some of the data's value is lost in the process of translating documents from Arabic to English.

- Some documents, although recent, were from one relatively short period of time. I was unable to access earlier documentation in order to make a comparative study. 


\section{Chapter Three}

\section{Theory}

This research talks about women and social services. This chapter will offer some of the theories surrounding the concept of social services, and attempts to describe the different concepts of social services, social welfare, social development, and gender empowerment.

\section{Social Welfare}

In their book "Understanding Social Welfare”, Ralph Dolgoff and Donald Feldstein offer a broad definition of social welfare: “...a nation’s system of programs, benefits, and services that help people meet those social, economic, educational, and health needs that are fundamental to the maintenance of society” (2000:112). Dolgoff and Feldstein also added that the priority concern is for social welfare for those who are disadvantaged, including the poor, ill, distressed, and vulnerable. They also stated that social welfare programs:

are intended to meet certain needs, deal with specific problems, or enhance life... implemented to achieve particular goals in relation to needs such as economic security, child care, and health care...to enhance life through such means as education, socialization, and recreation (137)

\section{Social Development Approach}

Social development is essential for every country because of the rapid changes taking place around the world. Change affects every aspect of today's life, and development is what makes this change positive. Development makes things better 
and improves the quality of life, but there are strategies and plans that should be enacted to achieve the development appropriately. The following section will explain a social development approach, with some examples for developing countries.

British colonial welfare officers promoted the idea of social development. These welfare administrators wished to introduce remedial programs linking social welfare services to economic development. In fact, social development specifically referred to two aspects of colonial welfare policy: remedial social work services and community development programs (Midgley 1997). The Declaration on Social Progress and Development, adopted by the General Assembly in 1969, emphasized the importance of a well-coordinated development approach that included both economic and human resources. In other words, the goals of development were seen, not only from the aspect of economics, but in terms of improvement in the overall quality of life.

Social welfare writers have neglected the social development approach, until the United Nations World Summit on Social Development (1995) drew attention to the approach. Midgley (1997) states that social development: “...is an approach for promoting human well-being that seeks to link social programs directly with economic development effort” (75). Social development approach proponents argue that economic development should be linked to social purpose. In fact, social development seeks to remedy distorted development by ensuring that economic development raises incomes and the level of welfare for all (Midgley 1997).

The term development deals with change. As countries change and modernize, there are some policies and programs that ensure that these changes are positive. According to the United Nations Developmental Social Welfare Survey (1986): 
Some of the more important developmental components of social welfare, in terms of corresponding policy and programme changes, include: (a) Maintaining a positive orientation toward the development of human potential (b) Having a comprehensive understanding of the interrelationships of needs (c) Bearing in mind the relevance of social welfare to all segments of the population (d) Meeting the total needs of specific population groups (e) Enhancing the social functioning and problem-solving capabilities of people through their active participation in their communities (f) Creating or modifying institutional processes conducive to optimum personal, community and national development.

One of the basic requirements for development is the gaining of knowledge. As stated in the United Nations Report of Human Development (2002): "It is an important dominion of human development as it is a critical means of building human capability" (19). It is generally known that education and knowledge are very important, yet in many countries and places there is a knowledge gap that affects their productivity and development. The Human Development Report suggested that working toward a knowledgeable society requires "multisectoral strategies that integrate absorption, acquisition and communication" (6). In other words, it is necessary to link educational systems, training systems, and the public and privatesector, so that educational development is seen as whole process. In addition, despite that education is a basic human right, it is also a critical means of enhancing human well-being and impacts all aspects of life. The report suggested that gaining effective educational strategies needed to begin with attitudinal change. This kind of change involves commitment at all levels of society, and requires a respect for knowledge, encouragement of creativity, raising productivity, and enhancing human welfare. This attitudinal change can be supported by policies that enhance social status and science and educational opportunities (United Nations 2002). 


\section{Theory of Social Development}

James Midgley (1995) described social development term as a "process of social change resulting in urbanization, the adoption of a modern style, and new attitudes” (2). Midgley connected welfare to development because it enhances people's income, education, housing, and health status. In addition, social development has produced impressive results in developing countries. He argues that in many countries, including developing third world countries, economic development has not been accompanied by an equal degree of social progress, which he refers to as “distorted development”. The problem caused by distorted development is that economic development fails to complement social development in a way that ensures benefits for the entire population. Midgley seeks the solution to distorted development in the social development approach because it offers a comprehensive and dynamic approach to promoting social well-being. His definition of social development is "a process of planned social change designed to promote the well-being of the population as a whole in conjunction with a dynamic process of economic development” (25).

Midgley argues that explanations of the causes of social change, ways of guiding the change process, and ideas and beliefs about what constitutes the ideal society, have influenced the thinking of social development. He examined the process of social development within a representational model. The process of social development is divided into three stages. The first stage is the pre-existing social situation, which social development seeks to change. The second is the social development process itself. The final stage, or the goal, is that which the social development seeks to attain. 
One of the major normative perspectives is "individualism”, which believes that their ideologies are most likely to promote human well-being. Individualist ideology, as explained by Midgely, makes individuals the primary concern of the society. These individuals are entitled to natural rights, freedom, and the ability to choose their future. Individualist ideology has its influence in the social development process. Advocates of the individualist approach argue that society can be improved through "self-betterment" and by enhancing the capacity of individuals. In addition, advocates of this approach believe that people must be able to function effectively and operate confidently in order to promote their own welfare. For this reason, steps must be taken, and strategies created, to assist these individuals and remove factors that impede effective functioning (Midgley 1995). The individualist ideology is the foundation for the creation of many programs for women in Saudi Arabia.

\section{Developing Countries}

According to Midgley (1995), developing countries achieved high rates of economic growth during the 1950s and 1960s. However, Midgley argues that there are variations in the extent to which government accomplishes positive economic and social change. Accomplishment varies according to the level of commitment, choice of development options, technical expertise, political realities, external and internal conditions, and other factors. Some developing countries in South America, northern Africa, southeast Asia, and the Middle East have experienced significant social gains. Still however, distorted development remains a major problem in these and other countries. In many of these countries, social opportunities have been enhanced, but are still subject to various social factors. For example, many Middle Eastern and South Asian countries still discriminate against women. Generally speaking however, 
there are new educational opportunities for women, and the participation of women in the modern economy has been clearly improved (Midgley 1995).

There are major problems facing developing countries. Distorted development occurs when there is a mismatch between economic and social development. Another problem is the adoption of western welfare approaches, which has occurred in many developing countries in the effort to modernize their societies. Many Third World analysts have concluded that the majority of people in developing countries have not benefited from western social services programs, and some have argued that it has had a negative impact on the countries’ welfare systems (Midgley 1995).

Taking the example of the Arab region, there has been remarkable progress in advancing human development over the last five decades, according to the United Nations Arab Human Development Report (2002). The report also described the changes and new challenges that currently face the Arab region under increased globalisation. However, the report argues that the success in meeting these challenges depends on countries' abilities to adapt to the demands of a new economic and political reality. This can be done by enhancing knowledge and advancing human freedom, with appreciation for the role of culture and values. All of that creates the foundation for human development in the Arab region.

\section{Social Welfare in Developing Countries}

The United Nations Survey on Developmental Social Welfare mentioned that the most important aspect of social welfare in developing countries is the "recognition of central position of mankind in development” (Untied Nations 1986:6). Generally, developing countries have realized the importance of human resources in the development process. In addition, in developing countries there are two essential 
elements of the developmental process, including social justice for all segments of the population, and the need to build the developmental welfare system within the existing social and cultural foundation. At the same time, these developing countries must adapt their institutions to new programs and to challenges posed by rapid modernization and change (United Nations 1986).

Formal voluntary organizations have been expanded in developing countries. Many non-formal associations such as local cooperative societies, and religiously inspired charitable and social action groups have also been created. Midgley argues that the success of the voluntary sector depends on governmental support (Midgley 1995). According to the United Nations Developmental Social Welfare Survey (1986), social welfare planning has become more and more integrated into development plans in countries such as Jordan, Kuwait, and Saudi Arabia. The vulnerable population (children, widows, aged, and unemployed) have been the main focus for social policy in these countries.

\section{Gender Empowerment Approach}

Empowerment has become a main goal for many development institutions like the World Bank, Oxfam and many non-governmental organizations (NGOs). By the 1980s, empowerment was being advocated as an essential tool for transforming unequal political, economic, and social structures. However, mainstream institutions see empowerment, as Parpart (2002) states, as “a means for enhancing efficiency and productivity within the status quo rather than a mechanism for social transformation” (339). Parpart adds that of two approaches to empowerment, some practitioners prefer to focus on personal empowerment, because without it, collective empowerment is impossible. Others focus on collective empowerment due to what 
they believe to be the "fragility of individual efforts." Parpart however, argues that in order to carry out effective change, empowerment requires attention to the role of identities and cultural practices, along with the forces that enhance power to act with others (2002).

\section{The Development of Women's Organizations in the Middle East}

Over the years women's issues have been a major subject of debates. Although these debates contain different opinions, motivations and concepts, they have always been innovative and have opened new paths for women. Women have been able to organize themselves into associations for the public good, and have often been in the position to empower other women. As Ellen Fleischmann (1999) has explained:

This activity usually took the form of charitable or social welfare organizations, which were established in some parts of the Middle East as early as the mid-nineteenth century. The first women's associations generally focused on improving the status of women through working in such areas as health; the care of poor women, infants, and orphans; vocational training; literacy (102).

Fleischmann argues that over time women's associations start to form explicitly for social welfare purpose. One of the primary motivations to organize such associations arose from a "sentiment of noblesse oblige" of the wealthy toward the poor among people in Islamic society. With both Muslims and Christians, the organizations they established were based on religion. This has changed, as some women's associations have started to separate themselves from being religious associations. Many of them however, still have religious members within the 
leadership of the associations. One of the first secular philanthropic societies was Mabbarrat Muhammad Ali, a dispensary for poor women and children founded in Egypt in 1909. In the beginning of the nineteenth century, religiously based charity associations were founded. These were followed by more social and political groups in the post World War I era. For example, the first women's association in Iran was involved in politics, and participated in the first constitutional crisis in 1906 (Fleischmann 1999).

According to Fleischmann, middle and upper class women had been supervisors of Islamic trust (awqaf) for centuries. They also were setting up and running charity organizations that required women to employ particular skills and to engage themselves in public activity. Fleischmann adds that women involved in the social welfare field have perceived this area to build power, which in many cases has lead to involvement in politics. The welfare arena has also provided new experience and has offered self fulfilment to these women, as this quote by Fleischmann exemplifies:

Women also discovered strength in collective work, and they experienced "self-discovery"; "working toward collective goals tapped wellsprings of creativity that had been quiescent.” They learned that they could wield authority and influence within a group, reducing the isolation and powerlessness they might feel as individuals and creating "new networks and bonds among themselves." They had to develop and use organizational skills, exercise control over resources, and manage their own organizations (103).

Most of the leaders and establishers of women's welfare organizations, as Fleischmann has described them, are educated middle and upper class women. Education has encouraged these women to seek changes and has given them the confidence and the ability to act. Also, these middle and upper class women have had 
more leisure and their class has had a major role in influencing their management and leadership. Many of these women see themselves as part of a women's movement even if the concept of "movement" does not necessarily refer to the mass of women in their society. Fleischmann also argues that these women generally have not tried to address the causes of social problems or to develop a deep understanding of social and economic distress. In fact, they tend to reflect many of the attitudes "of the male reformers, liberal politicians, and nationalists who were their allies during this period” (1999:104).

Women's organizations were established as a result of the recognition of the need for social welfare for women. These women's organizations carried within “a kind of tacit political act and implicit criticism of the deficiencies of prevailing political and social institutes (104).” In many cases these organizations existed before the government became responsible for providing such services. Through charity and welfare work, women started to establish relations and interact with governmental institutes and to seek support aside from the ability to negotiate with male officials (Fleischmann 1999). 


\section{Chapter Four}

\section{Women}

Throughout history, women have struggled to demand their rights and to achieve better status. Although women have achieved remarkable improvement during the past century, women around the world are still fighting for basic rights and higher status. Just being a woman in many countries means being more vulnerable and less fortunate. Women in Saudi Arabia are crossing the bridge that takes them to new opportunity and social positions that have never been achieved before. This chapter talks about women and vulnerability to poverty, women and welfare, and about Saudi Arabian women's positions in work and employment.

\section{Women and Poverty}

Many studies show that women are more likely to be poor that men. As Patricia Evans has argued in her article “Gender, Poverty, and Women’s Caring”, women's poverty frequently reflects their nature as "caregivers." She explains women's poverty as an undervaluing of women's work in the home and in the labor market, as a result of inadequate incomes for many single mothers who are without a male as a traditional financial supporter. Evans also explains that women's primary role being in the home, and the economic dependency on men is "natural”, and has made women’s vulnerability to poverty slow to gain attention (Evans 1998).

In another study, Christine Hallett shows the relationship between women's tasks and being vulnerable to poverty. Hallett (1996) argued that the household is "a key site of oppression with the reproduction of labor power (socially, in daily living,

and biologically, across the generations) provided by the unpaid domestic labor of 
women” (8). Woman's dependency on the male partner decreases a family’s financial capability because his job might not cover the entire expense of the family.

Strategies and policies should be made to deal with women's poverty in particular. Most strategies that attempt to fight poverty are not specially designed to address women. Moreover, most women suffering from poverty lack basic necessities and have other issues such as a lack of confidence, training, work experience, or education (Bush and Kraft 1998).

\section{Women and Welfare}

When the word welfare is mentioned, the first thing that tends to come to people's mind is that welfare is connected to women. Social welfare has been essential for many women around the world, and affects their whole life. According to Hallett (1996), “ In respect to social policy, Hernes (1987) has suggested that women have three major statuses: as service users, as providers, and as participants in the political processes affecting social welfare” (11). As users of services, women's unequal participation and their disadvantaged status in the labor market has made them one of the groups most vulnerable to poverty and reliant on welfare support. The traditional role that women have taken has made them the connecters, or " the brokers and negotiators”, between the family and the services. The caring nature of women

has made them seek services for their families, and as well, it is not surprising to find women as providers of social services.

\section{Status of Women Under Islamic Law}

In order to understand the Saudi system, including the status of women, it is important to understand the influence of Islamic thought on Saudi society. Muslims 
believe that Islam is not just a religious ideology, but that Islam has provided a comprehensive social system containing each small detail of everyday life. Under Islamic law, men and women have basic rights concerning marriage, divorce, property, inheritance, education, work, and in every aspect of life.

During the pre-Islamic period, women in the Arabian Peninsula lived in defeat and humiliation. The birth of a girl was seen as a disgrace, and burying girls alive was a widespread practice. With the rise of Islam, women were taken to a remarkable status in terms of respect, honour, and general standing. Islam came to rescue people from the darkness of ignorance, to extract the root of bad practices, and to stress the good characteristics of Arabian people that had existed since ancient times; characteristics such as generosity, braveness, and hospitality for their guests (AlMunajjed 1997).

In another study on women in Saudi Arabia, Abdulaziz Al-hazzaa (1993) has pointed out one of the great verses of Qur'an that show the moral and spiritual equality between men and women.

For Muslim men and women, for believing men and women, for devout men and women, for truthful men and women, for men and women who are patient and constant, for men and women who humble themselves, for men and women who give in charity, for men and women who fast, for men and women who guard their chastity, who engage much in God's praise, for them has God prepared forgiveness and great reward (Al Ahzab, 33, verse 35).

\section{Women in Saudi Arabia}

The fast economic development that began in the 1970s, brought attention to women's issues in Saudi Arabia in a way that could not be ignored, especially with social change that is still occurring right now. According to Al-hazzaa, the large number of unemployed female university graduates has caused great concern to the 
Saudi government. The government has created committees to discuss women’s roles in the development process, and the ways to enable women to integrate themselves within the Islamic framework. The government has been very careful in its approach to women's participation in public.

Segregation between men and women is a very visible feature of the Saudi society. For example, from first grade to university campuses, all public social events and parties are segregated. Al-hazzaa (1993) has indicated that it is not Islamic law, but more traditional patterns that have taken over. According to Al-hazzaa, family honour is critical, and determines the basis of male-female relations in Saudi Arabia. The male’s dignity and pride depends upon being responsible for his kinswomen economically, legally, and morally. As a result of this economic support, few women have the need to became financially independent by seeking better education or employment (Al-hazzaa 1993).

Under this social structure, dependency on males has caused a large portion of Saudi women to be unwilling to improve themselves. They would rather marry a man who will provide them a home with everything they need, and a salary from his earnings. Most of the time, education and employment simply becomes selffulfilment and a means to improve her social status. It is widely considered shameful for a Saudi man to let his wife support herself, and especially to let his wife support him. Traditionally, a man expects, and even desires to support his wife. Often, he will share his earnings with her, even if she has her own income. Recently, many working wives have shared support of the home, although they do so by indirect means in order to make the husband accept their participation.

In general, the Saudi woman has great influence as a wife and mother. Once the woman leaves her parents home, she begins to affect all family decisions. 
Sometimes women's power is not apparent, but inside the house, mothers have a strong influence over the husband and children. Moreover, motherhood is a very important role that every Saudi girl desires. Saudi women are "willing to explore an external source of prestige and satisfaction, however only to the extent that this does not exclude her from her motherhood role” (Al-hazzaa 1993:93). According to Alhazzaa, marriage is often desirable among Saudi girls, as they wish to escape parental control and supervision. Education and employment does not liberate Saudi girls from traditional family guardianship. In fact, working single women must live with their parents until marriage. For single girls, marriage is a way to freedom, a greater social life, and control over their own homes. The availability of expensive domestic maids and drivers in most homes enables many women to continue their education or go to their work (Al-hazzaa 1993).

\section{Education}

Before the discovery of oil in the 1930s, illiteracy was widespread among the population of the Arabian Peninsula. Tribal warfare and geography has made a large part of the peninsula live in isolation from the outside world. However, the western region, called Al Hijaz, which includes the two holy mosques of Mecca and Medinah, and the city of Jeddah on the Red Sea, have always been exposed to people, Ottomans having dominated the whole area. In 1880, the Ottomans established school systems exclusively for boys. Public education for girls did not exist, and they were only educated at home, learning the Qur'an and basic Arabic reading and writing. In the 1950s, some middle class families sent their daughters abroad to schools in Egypt and Lebanon. In addition, a group of educated men presented an appeal urging the 
government to establish schools for girls, and stated their need to have educationally compatible wives (AlMunajjed 1997).

The concern for education has increased with the economic development, which followed the discovery of oil. In 1953, the Ministry of Education was established, and the first public schools for boys were opened. Women's education in Saudi Arabia was introduced after King Faisal bin Abdul Aziz insisted that all Saudis should have equal educational opportunities within an Islamic framework. In 1956, King Faisal's wife Iffat founded the first private school for girls in Jeddah, and public education for women was first introduced in 1960. (AlMunajjed 1997).

The introduction of public education for girls brought great debate and was met with resistance, especially by conservative religious elements that claimed that public schools for girls would lead to moral corruption. King Faisal tried to convince conservative elements (Ulama) that Islam imposed no limits on the education of girls by quoting some verses of Qur'an, and Prophet Mohammed's sayings (Hadith) that education is important regardless of sex "Seeking education (knowledge) is mandatory for every Muslim.” (AlMunajjed 1997) In order to get the support of the conservative religious leaders, King Faisal appointed one of them to oversee the education of the girls. This later became the General Presidency of Girls’ Education. It was after the affirmation by the Ulama conservatives that families started sending their daughters to schools. Fifteen girls' schools were opened in Saudi Arabia in 1961, and by 1970 there were 55. More recently, according to the Ministry of Planning (1990-5), it was estimated that the number of female students graduating from secondary schools during 1994/5 was 111,402 compared with 113,544 in 1997 (AlMunajjed 1997). 
The establishment of the educational system in Saudi Arabia had a religious and traditional foundation. In fact, the educational system treats males and females differently according to the gender expectations of society. For instance, in the schools systems, boys are directed toward male activities and future job possibilities. On the other hand, girls' schools provide extra courses that stress the traditional roles of women in the society, including home management, childcare, cooking, and sewing. For many Saudi girls, the ultimate aim of life is to get married and become a mother (AlMunajjed 1997).

Higher education has also become available for girls in Saudi Arabia following the pattern of sending girls to universities in Egypt, Lebanon, England and the United States. In 1957, the University of Riyadh was the first to enroll women into the fields of art and commerce. In Jeddah, Kink Abdel Aziz University was founded in 1967. It began as a private college, and became a public university in 1971. Now there are seven major universities with separate campuses for women, and some of these universities have divisions in smaller cities. Education is kept segregated. Universities in girls' campuses have closed-circuit TV systems in order to include male teachers’ lectures from the males’ campus. Female students may specialise in medicine, natural sciences, mathematics, physics, arts and humanities (sociology, history, English or French literature, Arabic literature, geography, Islamic studies), library sciences, business/economics, and home economics (nutrition, family and child education, housekeeping, interior design).

According to AlMunajjed (1997), women need general programs for vocational training. In fact, there are governmental institutes for vocational training, but they only train women to become teachers. Recently, new private institutes and colleges have opened which provide programs and courses such as typing, computer 
accounting, interior design and other courses. There are also social services centers that offer some vocational training. As AlMunajjed described her experience “ In Jeddah I visited two welfare associations' centers where courses are held in typing, weaving, sewing, embroidery, languages and other manual work. In addition, lectures are offered on religious topics, nutrition and childcare. (1997:71)”

Personal influence has played an important role in the introduction of women's education in Saudi Arabia. As previously mentioned, in 1956 King Faisal's wife Efat founded the first private school for girls in Jeddah. The personal influence of Queen Efat over her husband, to officially open private school for girls, is worth recognition. Queen Efat was an educated woman that was born and raised in Istanbul, Turkey before marring King Faisal. At that time, it was not easy for a woman first to introduce the new idea of opening a school for girls, and then to rise to the challenge and accomplish her goal.

In 1965, just six months before Queen Efat's school opened, Sedekha Sharafaldeen established a private school in Jeddah called Alnaseefia. Sudekha made a pilgrimage from India with her family and stayed as guests in the Nasseef house in old Jeddah. The family stayed in this house because of the friendship between her father, who was an Indian scholar, and Mohammed Nasseef, who opened his house to foreign knowledge-seekers and scholars. Immediately, the ladies of the Nasseef house liked her and chose her to be a wife for their son Omar. They got married shortly thereafter. Sudekah was well educated and was shocked by the ignorance among the people of the area. However, she could not stay silenced, despite the new environment, people and traditions. She insisted on change, beginning with the way she raised her own children. 
Sudekah started to teach the women in the house, and gradually she reached out to the neighbours. Although she was also Muslim, she found widespread ignorance among the people of her own religion. The differences were attributed to a mix between religion and traditions. Few decades after her marriage, Sudekah gained considerable respect among Jeddah ladies. People in the community started sending their girls to her. Sudekah then decided to get permission to open a private school for girls within Saudi Arabia. First she talked with her father-in-law, who encouraged her due to his love for education. He helped her get permission from King Fiasal. Then, she met with a committee from the Ministry of Education who examined her knowledge. She began with one classroom in the Nasseef House while a building was under construction. She also brought teachers from Egypt and other Arab countries.

Efat and Sudekah are two examples of ladies raised outside Saudi Arabia who were introduced to the society, and worked hard to make a difference. As an outsider, a person can bring a fresh perspective to an environment, possibly having the capacity to introduce change. Of course, their upbringing, environment, and education contributed greatly to their ability to resist the existing situation in Saudi Arabia, and to introduce more positive alternatives.

\section{Employment}

Women's participation in the labor market is a major change from the traditional roles of women in Saudi Arabia. Economic development and modernization have created new employment opportunities for Saudi women. The Saudi female labor force was expected to increase, for example, during the fifth plan years (1990-95). It was estimated that the number of females entering the labour market was 60,200 or 10.5 of total labor supply (AlMunajjed 1997). 
No one can deny the reality of women's employment in the Saudi labor market. Thousands of female graduates expect to work each year, and questions continue to be raised concerning the participation of women in national development. The controversy that has risen over this issue has ranged from extreme conservatism, to those who favour gradual liberation of women into different types of employment (AlMunajjed 1997). According to Al-hazzaa (1993), self-fulfilment is the reason most Saudi women give on surveys concerning their employment.

Islamic law has allowed women considerable fortunes in their own right, and control over their inheritance. Most of women's employment in Saudi Arabia is provided by the public sector. Women can pursue careers in nursing, medicine, education, social services, or at banks or other private sector institutes. Still, the number of professions that women can pursue is limited. Businesswomen actively head their own work, regardless of the difficulties they face, due to the traditional nature of society. However, both private and public sectors have been active in helping women to gain professional and office skills (washingtonpost.com) Moreover, with technical assistance from the United Nations Development Program (UNDP), Community Development Centers can provide field experience, workshops, and training programs for social workers, of which women are about 30 percent of the total participants (Al-hazzaa 1993).

Al-hazzaa has suggested some major barriers to women’s employment, despite all the progress women have achieved. Working women still face many difficulties. Transportation is a major problem for Saudi women, since they are not allowed to drive. While some women use public transportation, many families still do not allow them travel alone. Most middle class families have drivers to take women to work or schools. Attitudes and stigmas exist regarding some occupations, such as vocational 
education. Working Saudi women also face the inability to participate in any decision-making process. There also exists a lack of women's professional organizations that can address women's work issues, career counselling, and training.

According to Mendel Alqabaa (2001), women's participating role in social and economic life is considered to be one of the most important issues in human resources development, labor force planning, and improvement in the levels of service and production. Alqabaa has suggested that to achieve the effective use of a woman's role, we have to share concepts of this effective role and strive to achieve plans, policies, and programs that take the Saudi woman to appropriate new roles according to the demands of society. Alqabaa also added that Saudi women should enter into new fields after they have proved their effectiveness in education, health, social affairs, media, and banking. Men and women are two parts of the human society in which they are both tools for development, and both strive for development at the same time. Men and women together have the means of production, and the ability to achieve development in human civilization. Therefore, relying on one part of human society, or on men only, in the provision of services or in the production process will neglect the other human element, which adds together to become the higher value in life (Alqabaa 2001).

In conclusion, women in general try to prove their ability to maintain balance among work, home, a social life, and children, and many women have been very successful in maintaining this balance. Saudi women have been very wise to address issues smoothly, maintaining power and influence within her family, and going out and proving the same in a social, economic life with a full understanding of the nature of traditional society. Her love for her family has not been enough for her to advance, but she has had the wisdom to find many opportunities, which will undoubtedly 
continue to expand. Still there are more challenges and opportunities to come, and many women are on the right path to achieve the success they desire. 


\section{Chapter Five}

\section{Social Services in Saudi Arabia}

\section{History of Social Work in Saudi Arabia}

Before the establishment of the modern Saudi state, social welfare was not practiced within professional institutes, although basic principles of social welfare, such as helping the poor or solving the problems of others was seen as brave tribal manners and the sign of a good man. The Arabian Peninsula has witnessed much instability, including civil wars and various social movements, and they have consistently lacked an adequacy of professional institutes. According to Almaglooth (1992), Saudi society was almost isolated until the 1960s, and life was simple. Few services were given to people from government resources. The population was relatively small, and unemployment was not a serious problem. Women, who made up half of the population, had almost no participation in the labor force, except for household work.

The discovery of oil has affected all aspects of social, economic and political life in Saudi Arabia. Accordingly, the government has changed from a simple government of a desert area, into a wealthy regime that has had to meet the complex challenges presented by both domestic and international power politics (Almaglooth 1992). However, the establishment of a welfare system was very critical in preparing the Saudi population to meet the challenges ahead. According to Almaglooth, the Saudi government has realized: “...it is important for social change to go hand in hand with economic and civilian development in order to avoid the civilian imbalance which may occur as a result of imbalance between the different aspects of civilization during its evolution” (1992:47). 
By the late 1960s, Saudi Arabia had experienced remarkable social transformations, which lead to the establishment of modern welfare institutes in different stages. Between 1912 and 1950, the first stage of the welfare state in Saudi Arabia was introduced, building a nation-state by integrating various independent tribes into a national framework. The problem of tribalism created a great obstacle to the emerging state. These various, independent tribal groupings, which made up about two-thirds of the population of the Arabian Peninsula, were uncontrollable because of their constant movement. King Abdul Aziz introduced the detribalization policy in 1912 as his first welfare program in settlement program form. Every tribe was allocated an area of land, and the state provided these settlements with free food, clothes, water wells, and basic education. This policy was very successful in settling, controlling, and finding employment for the people of these independent tribes.

After 1954, several political and economic problems threatened the legitimacy of the state. As a result, the second stage of the welfare state was introduced in 1962, as a tool for legitimizing the state. This stage provided basic social services. The last stage began in 1975, and continues to the present. Its main purpose is to maintain social stability. A modern welfare state has been developed that consumes over 50 percent of total state expenditures (Uthaimeen 1986).

According to Alsaif (1991), before World War II, primary institutions for social work practice and services in the Arabian Peninsula included tribes, families, relatives, and mosques. Social work education and practice in Saudi Arabia have since adopted western models. For instance, Egyptians and Saudi sociologists who studied in western institutes, developed departments for social work in Saudi Arabia. Supporters of this approach argue that with some modification, the principles of western social work will be useful for Saudi society. 
Alsaif (1991) argues that only recently has it been recognized that imitation of the western social work model does not always suit local needs. In addition, Alsaif has suggested that the legitimization of social work in Saudi Arabia could not be achieved without gaining public recognition. In order to gain public recognition, social work must prove its ability to deal with local needs, and should reflect Saudi economics, politics, and culture.

\section{Social Welfare in Islam}

One of the fundamental requirements of Islam is the obligation to charity. One form of charity is Zakah, the obligation of giving alms. This type of charity requires that one give up at least 2.5 percent of one’s wealth once a year. There are different types of people that are eligible for Zakah, among them the poor, travellers, Muslims in debt, workers who collect charity, and the state. Another form of charity is Sadaqah, giving charity on a voluntary basis; for example, distributing a quantity of dry food like grain to the poor at the end of Ramadan. A waqf is another form of charity in which property is given by will, or as a gift to the Islamic state for public good, such as building mosques and schools (Dolgoff and Feldstein 2000).

\section{Ministry of Social Affairs In Saudi Arabia}

This section provides descriptions of the social services provided by the Ministry. One of the major services that were extended through the Ministry of Social Affairs is the program of personal social services, which is divided into the following services. 


\section{Community Services}

The Saudi government's first concern for its citizens is providing free services to each citizen; services such as health, education, etc. However, it has also come to realize that it is equally important to focus on each citizen as a human being who works, affects others, and has individual expectations and values. Therefore, the government has introduced social development as a technique to meet local communities' needs, and to achieve the appropriate balance of citizens' physical and intellectual capabilities. This began with the first community development center, established in 1960 in the Al-Diriyah village, in central Saudi Arabia. According to Almaglooth, there are clear objectives for community development programs, including:

1) The development of human and financial resources in the community. 2) The revival of cultural, health, social, and economic aspects. 3) An attempt to correct the customs and the abnormal concepts. 4) The cooperation with citizens in studying their needs and finding a practical solution for their problem along with their participation in providing the necessary resources to meet these needs (1992:48).

Under this program, there are several areas of interest, including community development, general education, and culture. These areas of interest have been translated into two major sections. Community Development Centers provide for the needs of those living in rural areas, and Social Services Centers serve urban areas. These centers provide personal and collective services to local communities such as medical treatment, teaching basic skills, and training for girls in sewing, housekeeping, and education for mothers (Uthaimeen 1986).

Within one year, this tentative program made remarkable steps toward achieving its goals. A committee of citizens worked with workers in these centers to 
design new programs such as sports clubs, illiteracy prevention classes, clinics, health awareness programs, childcare, and others. Due to convincing results, and a positive impact on some of the social behaviour of citizens, the government expanded the tentative programs into permanent centers for training and development. Now, in addition to the Center for Training and Applied Research in Community Development in Al-Diriyah, there are 22 centers throughout the country, including 6 urban community centers and 16 rural centers. Also, in other areas where no community development centers were available, 20 additional committees were created to supervise the local community and provide for their needs (Almaglooth 1992).

Each community development center consists of three sections; social, cultural, and health, in addition to an agricultural section in rural areas. According to Almaglooth (1992), the social section directs programs that encourage social participation and the improvement of the lives of individuals. These programs include local committees, rural clubs, youth summer camps, women's committees, kindergartens, individual problem-solving, and house visits. The cultural section encourages the educational level of the community by building libraries, fostering adult literacy, and cooperation with school activities. The health section works through health education, clinics, and extension services.

\section{Role of Social Workers in Community Development Centers}

Although there is a written document, which describes the role of social workers, it has never really changed since the establishment of the community centers. Therefore, the role of the social worker in Saudi Arabia is not clear. Almaglooth argues that the document still needs to be updated and the roles clarified, to be able to work effectively and achieve its goals. In community development 
centers, both males and females are social workers, but they work in separate buildings. For example, each center is divided into two sections, one for males and the other for females. Both are under the director of the center, who plays an important role as a connection between them (1992).

Almaglooth has provided a summary of the role of female social workers in community development centers. Some of these are:

1) To make the women aware of the customs and traditions which might weaken the society and direct them to the kind of customs that help to increase the level of social, economic and health status of families. 2) To organize programs for women that fit their different activities and interests and to help them gain the information and productive skills needed to increase the family's income. 3) To offer educational classes for women and girls during the day to teach them reading, writing, social skills, health and home economics...4) To formulate a women's committee consisting of women from the village where they can gather together with the social worker in order to direct other women from the village about what might happen if bad or unfavorable customs or habits emerge and try to change such unfavorable habits gradually (1992:60).

According to Almaglooth, there are several factors, which affect the implementation of social work practice in general, and in community development in particular, in Saudi Arabia. The first factor concerns bureaucracy, as a social worker cannot do his or her job effectively due to restrictive bureaucratic rules and regulations. Second, the social training centers, even in cooperation with schools of social work, are not qualified enough, and do not ensure sufficient training for its students. Another factor, which has weakened the social work practice, is the lack of awareness of community members toward social work. 
The Agency of Social Affairs is a Ministry of Labor and Social Affairs’ Agency. It provides social care for citizens who face economic and social problems, and helps them to face these problems. The agency makes every effort to equip these people to face problems in the future. The Agency of Social Affairs was established in 1960, and its objectives complemented national development plans by raising standards for society, family, and the Saudi individual. The general objectives of the agency, according the Ministry of Labor and Social Affairs, are the following:

1- Improve the qualification of the social agency sections to carry out their role effectively and sufficiently.

2- Put forth long term plans for social research and studies, and determine priorities according to latest social development.

3- Provide social care for individuals inside social care institutes.

4- Provide social care for individuals and families in their own environments.

5- Provide care and guidance for juveniles in the social care institutes.

6- Increase care for family issues programs.

7- Increase care for individuals with disabilities by adding new, improved programs to rehabilitate and care for them.

8- Assure that individuals and groups participate to improve the local community through voluntary activities.

9- Improve social development activities to meet the increasing demand of society.

10-Continue to support and encourage cooperative activity, and spread and improve cooperative association services.

11- Improve awareness and social guidance programs. 
The Agency of Social Affairs carries out many different tasks that are relegated to different divisions., Following are the specialized divisions of the agency:

\section{Training and Social Research Center}

This center supervises the observation and analysis of variables and social problems, and conducts social studies and research in coordination with all the agencies’ divisions. The center also develops a specialized work force for the agency and its branches through training programs.

\section{Women's Supervision Offices}

This division supervises different institutes, which deal with women's issues, and makes sure they achieve desired goals and tasks. Under the General Administration for Women are the following sections:

- Family Section: works to achieve proper social stability for the family, and emphasizes the importance of family unity.

- Childhood Section: works to prepare for family stability by caring for children inside nurseries, and makes sure those families who adopt children take good care of them.

- Women's Supervision Offices: supervises the performance of the centers, institutes, and women's associations in the different regions, and help these institutes achieve desired goals. 


\section{General Administration for Rehabilitation}

This division works to provide rehabilitation and social services for all kinds of disabilities. Under this administration are several specialized sections, described in the following:

- Basic Equipment Section: provides the basic equipment that specializes in serving and rehabilitating people with disabilities.

- Social Rehabilitation Section: works to ensure a good social life for every disabled individual, in hopes of achieving social integration for him or her.

- Vocational Rehabilitation Section: works to rehabilitate people with all kinds of disabilities, training them according to their individual abilities and needs. This section also gives authorization to private centers for handicapped and disabled people, and supervises their programs and activities.

- Aid Section: provides cash aid for disabled people who live with their families; also provides cash aid for personal and group vocational projects for training the disabled. This section also provides cash aid for families with paralyzed children, and aid for families that take care of nursery children, either substituting or nursing families with nursing end rewards. In addition, it provides aid for wedding expenses to girls who live inside the social care centers.

\section{General Administration for Care and Social Guidance}

This administration specializes in setting general policies for care, education, guidance and behaviour correction for people with special conditions. This is done with regard to Islamic religious values. Several divisions under this administration include the following: 
- Social Education Division: works to introduce care and correction principles to orphaned children and other children from 6 to 12 years old, who have social circumstances which prevent them from living a normal life with their families.

- Mendicancy Prevention Division: works to achieve the principles of appropriate guidance and correction for the mendicant, and prevents the mendicancy phenomena in coordination with other governmental authorities.

- $\quad$ Elderly Care Division: works to ensure proper care for the elderly.

- Sheltering Services Division: provides services such as housing, living expenses, clothing, and transportation for children, orphans, delinquents, and the elderly.

- Delinquency Care Division: provides principles for the guidance and correction of deviant delinquents.

- Girls' Care Institutes: provides care and social correction for juvenile girls under 30 years old who stay in the institute, and provides appropriate health, educational, and training care.

\section{General Administration for Social Correction}

This administration provides guidance and reform principles for released prisoners, and the drug and alcohol addicted. Under this administration are several specialized sections, described as the following:

- Restoration Social Acceptance: works on guidance and counselling for recently released prisoners according to scientific methods.

- Restoration Social Adaptation: provides principles for comprehensive care for drug and alcohol addicts. 
- Social Stability: works to guide and care for social institutes’ graduates.

\section{Social Research Center}

This center works to improve current methods and procedures for accepting and studying cases, and determines who qualifies for social services.

\section{General Administration for Private Institutes and Associations}

This administration works to achieve cooperative principles and social voluntary work, and draws executive plans for cooperative and private voluntary work. Under this administration are several sections, according to the following fields of specialization:

- Charity Institutes and Associations Division: works to encourage private social services and voluntary charity associations and supervises their activities, and carries out all the procedures for the registration process and supports them financially and technically. This division also reviews final accounting records and sets the plans, programs, systems and procedures that help these organizations carry out their tasks effectively.

- Cooperative Societies Section: works to develop and spread cooperative awareness among citizens and encourages the establishment of cooperative societies. They also supervise the implementation of plans and policies that were adapted in this field, in addition to reviewing annual reports (Ministry of Labor and Social Affairs 2003).

Table 5.1 shows numbers of social services beneficiaries in private social welfare organizations in Saudi Arabia for every five years. As illustrated, there is a huge 
increase in the numbers of social services beneficiaries between the 70s and the 90s. Specifically, when comparing childcare and education/training, both began with around 4000 beneficiaries. While childcare increased dramatically every five years, the training and education category was very slow to increase until 1995. After 1995, there was a sudden increase from 40,000 to 80,000 in just two years. This indicates a drastic change in attitude toward training and education. Not only has there been a huge increase in the training and education category, but in all programs of social services.

Table 5.1- The Development of the Charity Associations Programs

\begin{tabular}{|c|c|c|c|c|c|c|}
\hline Beneficiaries & \multirow{2}{*}{ Childcare } & $\begin{array}{c}\text { Training } \\
\text { and }\end{array}$ & $\begin{array}{c}\text { Handicapped } \\
\text { and Elderly }\end{array}$ & General & Health & General \\
Year & & Education & Care & & Assistance \\
\hline $1970-75$ & 4870 & 4293 & - & 873 & - & 48527 \\
\hline $1975-80$ & 19559 & 6536 & 275 & 4687 & - & 140930 \\
\hline $1980-85$ & 54536 & 34075 & 1737 & 27388 & 191158 & 376255 \\
\hline $1985-90$ & 89454 & 41534 & 3276 & 28685 & 977735 & 956684 \\
\hline $1990-95$ & 93708 & 48151 & 9535 & 37969 & 996981 & 1674510 \\
\hline $1995-97$ & 35762 & 85956 & 13140 & 21712 & 294102 & 791598 \\
\hline
\end{tabular}

Source: Ministry of Labour and Social Affairs 1999.

\section{General Administration for Social Development}

This administration specializes in achieving social development and ensures safe and appropriate change for the individual, the family, and the society. This 
administration also sets executive plans for social promotion and development programs. Under this administration, there are two sections:

- Social Development and Awareness: works to develop and improve local communities and make desired changes to achieve development and social balance within the framework of Islamic values. Also works to free society from unwanted social traditions and ideals.

- Social Improvement: works to improve and modernize social development plans, programs, and activities.

\section{Content Analysis for Social Services Associations}

A code sheet has been prepared for the social services agencies. The code sheet has a number of specific codes, detailed according to specific questions. The codes were chosen to meet exact words in the documents. The content of these agencies have been analyzed in terms of their main goals, targets, basic message to clients, training and educational programs, and their statistics. The main question is: What do these agencies are offering for women to help improve their lives? The codes were organized according to the following model, starting with the role that these agencies play, their targets, purpose, and methods. 
Table 5.2- Code Sheet for the Content analysis of Agencies

\begin{tabular}{|c|c|c|}
\hline & Code & Definition/ Examples \\
\hline Aim / Act & $\begin{array}{l}\text { Social Development } \\
\text { Improvement } \\
\text { Enhancement } \\
\text { Rehabilitation } \\
\text { Care } \\
\text { Training }\end{array}$ & $\begin{array}{l}\text { Each of these words were specifically used within the } \\
\text { examined documents. }\end{array}$ \\
\hline Target & $\begin{array}{l}\text { Families } \\
\text { Women } \\
\text { Children } \\
\text { Men, Women, and Children }\end{array}$ & As target recipients. \\
\hline Aimed at & $\begin{array}{l}\text { Life in general } \\
\text { Social status } \\
\text { Economic status } \\
\text { Awareness } \\
\text { Knowledge } \\
\text { Skills } \\
\text { Opportunities }\end{array}$ & $\begin{array}{l}\text { What is the aim of development? What is the goal of } \\
\text { improvement? In other words, what are the services } \\
\text { trying to enhance? }\end{array}$ \\
\hline
\end{tabular}




\begin{tabular}{|l|l|l|}
\hline Tool/Services & Financial assistance & \\
(through) & Clothing and Staple food & \\
& Health services & \\
Educational/training services & e.g. Courses and workshops, literacy classes, lectures, \\
& Handicapped services & cultural competitions, library, and educational \\
& Social worker visits \\
& Counselling \\
& Lodging for women \\
& Orphanage houses \\
& Charity markets and events \\
& Daycares and kindergartens \\
& Studies and researches & \\
& \\
&
\end{tabular}




\section{Ministry Agency of Social Affairs}

This agency is the only public institution under observation in this study, and all the sections of this agency have been described earlier in this chapter. The content analysis includes two documents. The first is a special edition report for the 100-year anniversary of the establishment of Saudi Arabia. The second is a booklet for the Social Affairs Agency for the year 2003.

\section{Manifest Analysis of the Social Affairs Agency}

Aim: There are several things the agency aims to enhance and improve. Two main goals for the agency concern a woman's primary role in the family, and her social development. The agency's key words are care and support, as it is concerned with family care and supporting its closeness. The agency also aims to enhance awareness and provide guidance for families to raise their children effectively. It coaches ladies and mothers on the importance of the family, and warns about what might have negative effects upon it. The agency also provides scientific programs on motherhood and childhood, and enhances mothers' general social and health knowledge. It trains women in hands-on skills which can help them financially and can also occupy their spare time. Finally, it issues publications that provide guidance about appropriate child-rearing skills and behaviors.

The agency also has social development projects which provide special programs for women and children. These programs aim to provide knowledge and educational programs which enhance women's cultural awareness and help to increase her confidence and participation within society. The agency also has offered productive families projects and women's factories, which can provide employment for women who have graduated from the agency’s training courses. 
Women: The agency has a separate administration for women that offers its own services to women and children. Despite the provision of services that aims to provide knowledge and employment, the agency still has focused more on the role of women in the family than on her own independence.

Social Services: There are many services that the agency use to achieve their goals. Training courses are offered in sewing, family budget, interior design works, flower arrangement, typing, computers, English, Qur’an studies, and literacy. It also provides lectures and publications which aim to increase women's awareness and knowledge.

\section{Document Layout}

The first document is a 1999 special edition of the Ministry of Labor and Social Affairs for the 100-year anniversary of the establishment of the Kingdom of Saudi Arabia. The title of this document is The Establishment and Development of Social and Labor Services in Saudi Arabia. This document has many details, with more than 300 pages, starting with the history of the Ministry and followed by the Ministry’s different sections. Each section has details of each agency's administrations and divisions. Although this document is very detailed, most of the detail is explained in charts and tables. Every few pages, there is a picture of a facility.

The second document is a booklet of the Social Affairs Agency for the year 2003. This document has brief descriptions of different administrations and divisions under the agency. The document also includes the agency's goals, activities, programs, and projects. Each page has colourful pictures of facilities and activity. On the back of the document, they offer the agency's fax and phone numbers, and the agency's website. 


\section{Women's Welfare Society}

The Women's Welfare Society was the first welfare organization in Saudi Arabia in 1963, registered No. 1 at the Ministry of Labor and Social Affairs. The idea originated more than 38 years ago, from a woman named Jehan Alamawi. She introduced the idea of establishing the first charity association to the Ministry of Labor and Social Affairs, and found support and encouragement. However, this establishment needed private support as well, so she introduced the idea to about 20 of Jeddah city's society ladies, and they were also very supportive. The first committee meeting had 7 members, and later membership increased to 12 . With this cooperation, the Women's Welfare Society opened in 1963, to meet society's demands concerning the welfare of its women and children. A year later, Queen Efat was chosen honorary president of the Welfare Society.

Since its establishment, the Women's Welfare Society's aim has been to help needy women and children by providing different social services. The women's society had put forward certain objectives, described in the following:

1- Provide financial and material assistance for needy families, following a field study for each case.

2- Provide child care at all stages of development.

3- Provide religious, cultural, and educational care for women and girls.

4- Raise women’s awareness through lectures and workshops.

5- Provide different educational courses for women.

6- Provide shelter services for handicapped people, orphans, and prisoners' children.

These objectives are being addressed though different services and activities such as the following: 
- Regular visits to needy families by social workers, to assess needs and evaluate change.

- Supervising 20 free homes donated by private citizens, and assisting elderly residents.

- $\quad$ Supplying the physically handicapped with proper equipment.

- Distributing staple food and clothing twice a year, and fresh food once a week.

\section{Manifest Analysis of Women's Welfare Society}

There are three types of documents from the Women's Welfare Society. They include a small booklet, a special edition annual report for the 37-year anniversary of the society's establishment, and a folder with 6 small brochures. Each of these 3 documents have been subjected to two types of content analysis. The first will focus on the availability and quantity of certain words.

Aim: The main goal of the association is to help needy women and children by providing social services. The Women's Welfare Society has provided for these goals. In the introduction to its anniversary report, the there are several phrases that describe their perspective about women they are serving. First, it describes the establishment of this first charity association as a "natural response of social development.” Then, it describes the foundational members: "The endless effort of these enlightened ladies has begun, and it came form their sense of responsibility and their deep belief in the importance of women's participation in the practice of social welfare” (WWS 1999). In this quote, the women have been described as knowledgeable, and as believers in the abilities of Saudi women to participate in social life. In another part of the introduction, it describes the first services of the Women's Welfare Society; “The community waited to see what Saudi woman could contribute to this field...this 
association has taken on the lead role in proving the presence and participation of the Saudi woman in the creating a unified society. It has also paved the way for other women’s associations in Saudi Arabia” (WWS 1999)

Four out of seven goals mention women as a main target for care, development, and rehabilitation. One goal states that the association aims to provide cultural and educational care for women and girls. Another goal is to provide social, health, and economic care for them. Raising women's and girls' awareness through lectures and seminars is the third goal. The fourth goal is to rehabilitate girls through different educational courses. Obviously, there are three kinds of acts; care, enhancement and rehabilitation, which target the educational, cultural, health, social, and economic aspects of women's lives. Also, the development acts aim to increase overall awareness of these women within society.

Women: This organization was the first welfare organization in Saudi Arabia, and it was also the first to specialize in women and children. Private effort and support came from abut 12 ladies, who were establishment members. It is in fact, a lady who had the idea to establish the organization, and who had the thought and courage to present the idea to the Ministry of Social Affairs. It claims women as its main target; "This association was established to meet society's demands in such areas as motherhood and child care, social and health care, women's rehabilitation, counseling and financial assistance.” The word rehabilitation refers to retraining women to be more capable in achieving higher social and economic standards.

Social services: As previously described, the Women's Welfare Society offers different services which range from providing basic needs to offering educational courses. However, the services that encourage women toward a higher sense of wellbeing are the key focus. The brochure from the Women's Welfare Society shows the 
actual achievements for the year 2002 and introduces several divisions, every division being responsible for a number of services and activities. There are a few activities and services represented from each division. The social division developed the productive families project, which encourages families to produce traditional clothes and handicraft art works, and then sell them for family benefit. Also, in cooperation with other private organizations, the special arts program was developed to teach women who live in the association's lodging, or women who live in families receiving assistance. This program offers embroidery and sewing, and set exhibitions in which to sell their products. Moreover, the social section offers skills development courses for social workers and provides them with certificates for graduates.

The training and cultural and occupational rehabilitation section offers many courses to train women and improve their skills in computer and Internet courses, which in the year 2002, graduated 143 women. Besides English and French courses, the training section offers beauty and hair care professional courses, and in the same year, 50 female graduates were given certificates to qualify them for work in beauty centers. The training and cultural rehabilitation section provides lectures and educational and cultural competitions to enhance general awareness among Saudi women. In addition, the health section provides regular lectures and workshops tp promote family health awareness and awareness of other health issues.

Personal influence: Jehan Alamawi, founder of the Women’s Welfare Society, was the first in Saudi Arabia with the idea to establish a private charity association. Almawi's family originally came from Palestine, but later became Saudi nationals. She was well-educated and had a deep belief in the abilities of women. At the end of the 2000 annual report, there is an interview with Almawi. She was asked about the factors behind the success of her idea, and she answered that the enthusiasm of the 
Minster of Labor and Social Affairs at that time, and his belief in the idea, were major factors. She also described for the Minister the availabilities of many women with free time to help others, the demand for women's contribution to society, and the importance of opening charity associations that these women could participate in to provide social services. The second factor, as she described, was the enthusiasm of the establishment's female members and their sincere efforts, hard work, financial support, and their stand against all the opposing forces which face any new endeavour. The last factor, the acceptance of princess Efat as honorary president, was a great benefit to the association, and real support for voluntary social services.

\section{Document Layout}

The annual report for the year 2000 was a special edition for the $37^{\text {th }}$ anniversary. Basically, the report describes the objectives, activities, and different services that are provided by the Women's Welfare Association. After a brief introduction, the report provides a section called "words we are proud of" that show the actual handwriting of some of the high ranking officials and ministers who visited the association, and wrote some personal impressions. Then the report offers a summary about the establishment of the association, and names the first 12 establishment women members. After the presentation of the objectives and services, the report offers more names of women who have been members for more than 10 years, and the current administrative board, which consists of 14 women. Different administrations and sections and their responsibilities were described in detail and took up half the report. The presentation of information in this report is clear and brief. It provides numbers and statistics. It also provides pictures of exhibitions, building, and activities.

The Women's Welfare Society offers a small booklet which is divided into two sides, one side in Arabic and the other in English. This booklet provides 
information in brief sentences. Every page has a picture. For example, the page on general social services has a picture of women receiving staple food, and the educational services show the association's library. The last two pages show the origin of funds and resources. The last page also offers the association's numbers, addresses, account numbers for donations, instructions on becoming a member, and special thanks to donors and contributors.

\section{Alfaisaliha Women's Charity Association}

Alfaisaliha Women's Charity Association was established in 1976. The establishment committee consisted of a group of princesses and society ladies who put forward the association's objectives to be approved by the Ministry of Labor and Social Affairs. There are many different activities that have been carried out by the association, but the most important tasks are the following:

- Providing financial assistance for needy families, and providing them with necessary social and health care.

- Orphans’ care in the association’s lodging centers.

- Handicapped rehabilitation and care in all areas that relate to disabilities.

- A training and vocational rehabilitation center which provides vocational training courses, and offers scholarships for courses for families with limited incomes.

- A center for handicraft and industrial production.

- Enhancing social and cultural awareness on current social issues and problems through lectures and workshops.

- Enhancing the generation's culture and traditional heritage through parties and exhibitions. 


\section{Manifest Analysis of Alfaisaliha Women's Charity Association}

There are two sources for the Alfaisaliha Association; an annual report for the year 2002, and a report called "Labor and Social Affairs" in a periodical issued by the Ministry of Labor and Social Affairs (2nd edition, September 2000).

Aim: Enhancing women's awareness is stated as the main goal for the Alfaisaliha association. There are several instances in the Alfaisaliha document describing actions taken to improve women's conditions including training, production, employment, improvement, and general support. They also describe their achievements as comprehensive contributions in the development of human resources in the areas of health, protection, and development.

Women: The association's objectives are to enhance women's awareness in the Saudi society and to serve them in many different social, cultural and health areas. Women are the main targets of the association, besides needy families. The association not only provides services for beneficiaries, but also offers community awareness for ladies through lectures and workshops, which hundreds of ladies regularly attend.

Social Services: There are several kinds of services that the Faisaliha association offers in terms of enhancing and improving women skills and status. The center for training and occupational rehabilitation offers courses for women in sewing, handicraft arts, beauty, computers, and English. This center also provides free courses and educational scholarships for limited-income families. Moreover, the center provides training for teachers and assistants working inside the association, as well as professional training for staff at the handicapped center. There is another center for handicrafts and industrial production, which provides employment in the labor force for handicapped women, and women in needy or limited-income families. 


\section{Document Layout}

The Faisaliha annual report for the year 2002 began with special thanks for donors and contributors. The report is divided into sections, each section having descriptive information about its activities and responsibilities. The report shows names of donors and the association's members and staff. A whole section is devoted to media coverage of the Alfiasaliha women’s association during 2002. The last part of the report provides descriptive budget tables from a professional accounting office. The report did not offer any numbers or addresses for the association.

\section{Albir Association}

Albir association was established in the city of Jeddah in 1982. It is a charity organization which provides services for the Jeddah area and its surrounding villages, under the supervision of the Ministry of Labor And Social Affairs. Volunteer members of the association are elected every 3 years, and committee members decide on plans and programs, and act as supervisors. The Albir association also participates in the activities and efforts of the world organization of the United Nations, which has enhanced the association's expertise and knowledge, especially in the area of childcare. Some of the association's objectives are included in the following:

- Provide assistance and aid for all who need social assistance, such as needy families and orphans.

- Establish homes and institutes to lodge and care for orphaned children and children with special conditions. Establish nursing homes for the elderly.

- $\quad$ Provide training courses for the association’s beneficiaries. 
- Set up festivals and charity markets to gather donations and to introduce the association and its activities.

- Conduct social research and studies, provide awareness and guidance services, and conduct lectures and evening charity events.

- $\quad$ Provide health aid and care for the poor.

- $\quad$ Provide family therapy and social guidance for married couples.

\section{Manifest Analysis of Albir Association}

There is one annual report for the Albir Association for the year 2001. I will provide a content analysis for this report.

Aim: The main aim of the association is to provide social services to the people of Jeddah and the surrounding areas. The concept of developing resources repeats several times when describing educational services for Albir. The annual report of the Albir association provides very brief descriptions, so there were no other words to describe its aim, except for the words provide, offer, and develop.

Women: Although the Albir association provides services to both men and women, there is a separate section for women. In the annual report for the year 2003, it mentions the reason for establishing a women's committee is to support women's participation in different social activities, to encourage women's support for charity activities, to make field visits to families to assess conditions and provide assistance, and to conduct lectures and meetings in the women's societies.

Social services: In terms of providing services for women, the Albir association offers training courses and provides regular lectures on social and women's issues. For the year 2002, the women's section has 620 registered families receiving assistance, consisting of 84 widows, 53 divorced, 74 ill, 245 improving, 53 elderly, 
and 14 prisoners' families (www.albir.org). However, the Albir association is more widely known for its girls’ orphanage homes. In these homes, a girl stays until she gets married, at which time the association helps in marriage procedures and expenses, and offers monthly aid.

\section{Document Layout}

The Albir association's annual report offers its information in brief, and includes lots of pictures of children and buildings. The report has many charts, which include facts and statistics about the association, using a colourful layout. The report also offers a descriptive budget report for the year 2001 of all funds and expenses. The last two pages of the Albir report include a membership application, membership rules, and membership advantages. The last page offers the association's addresses, bank account numbers, and web site and e-mail address. 
Table 5.2- Summary of the Content Analysis of the Four Associations

\begin{tabular}{|c|c|c|c|c|}
\hline & $\begin{array}{l}\text { Agency of Social } \\
\text { Affairs } \\
\text { Women Section }\end{array}$ & $\begin{array}{c}\text { Women's Welfare } \\
\text { Society }\end{array}$ & $\begin{array}{c}\text { Alfaisaliha Women's } \\
\text { Association }\end{array}$ & Albir Association \\
\hline Type of Organization & $\begin{array}{l}\text { Public/ } \\
\text { governmental non- } \\
\text { profit }\end{array}$ & Private, non-profit & Private, non-profit & Private, non-profit \\
\hline Women as target & $\begin{array}{l}\text { Has a separate } \\
\text { administration for } \\
\text { women and } \\
\text { children. }\end{array}$ & $\begin{array}{l}\text { Women and children } \\
\text { are main targets. }\end{array}$ & $\begin{array}{l}\text { Women and children } \\
\text { are main targets. }\end{array}$ & $\begin{array}{l}\text { Has a separate section } \\
\text { for women and } \\
\text { children. }\end{array}$ \\
\hline $\begin{array}{l}\text { Descriptions of } \\
\text { women }\end{array}$ & $\begin{array}{l}\text { Mothers or women } \\
\text { within the family } \\
\text { context. }\end{array}$ & $\begin{array}{l}\text { Women or girls were } \\
\text { mentioned } \\
\text { independently }\end{array}$ & $\begin{array}{l}\text { Women or girls were } \\
\text { mentioned } \\
\text { independently }\end{array}$ & $\begin{array}{l}\text { Women not } \\
\text { specifically targeted. }\end{array}$ \\
\hline $\begin{array}{l}\text { Acts and words that } \\
\text { used to refer to } \\
\text { women }\end{array}$ & Enhance awareness & $\begin{array}{l}\text { Enhance, care, and } \\
\text { rehabilitate }\end{array}$ & $\begin{array}{l}\text { Enhance, support, and } \\
\text { train }\end{array}$ & $\begin{array}{l}\text { General words that } \\
\text { described both men } \\
\text { and women. }\end{array}$ \\
\hline Main Aim & $\begin{array}{l}\text { Achieving social } \\
\text { development }\end{array}$ & $\begin{array}{l}\text { Helping needy } \\
\text { women and children } \\
\text { by providing health } \\
\text { care and different } \\
\text { social services }\end{array}$ & $\begin{array}{l}\text { Enhancing women's } \\
\text { awareness and } \\
\text { providing different } \\
\text { social, cultural and } \\
\text { health services to } \\
\text { those of different ages } \\
\text { and social statues. }\end{array}$ & $\begin{array}{l}\text { Providing social } \\
\text { services for Jeddah } \\
\text { and the surrounding } \\
\text { areas }\end{array}$ \\
\hline
\end{tabular}




\begin{tabular}{|c|c|c|c|c|}
\hline $\begin{array}{ll}\text { Programs for } \\
\text { enhancing knowledge } \\
\text { and skills }\end{array}$ & $\begin{array}{l}\text { Educational/ } \\
\text { training courses, } \\
\text { lectures, educational } \\
\text { scholarships, } \\
\text { publication, and } \\
\text { production center. }\end{array}$ & $\begin{array}{l}\text { Educational/ training } \\
\text { courses, lectures, } \\
\text { book fairs, cultural } \\
\text { competitions, daycare } \\
\text { for working mothers, } \\
\text { recreation activities, } \\
\text { educational } \\
\text { scholarships and } \\
\text { production center. } \\
\text { Conducts field } \\
\text { research to follow up } \\
\text { with cases. }\end{array}$ & $\begin{array}{l}\text { Educational/ training } \\
\text { courses, lectures, } \\
\text { educational } \\
\text { scholarships, } \\
\text { recreational activities, } \\
\text { and production center. } \\
\text { Also conduct social } \\
\text { research to improve } \\
\text { services and evaluate } \\
\text { needs. }\end{array}$ & $\begin{array}{l}\text { Educational/ training } \\
\text { courses, lectures, } \\
\text { educational } \\
\text { scholarships. Conduct } \\
\text { social research. }\end{array}$ \\
\hline Years of experience & 43 years & 41 years & 28 years & 23 years \\
\hline
\end{tabular}

From the previous table, one can see that all four institutions have similar services for women. There are slight differences in the courses they offer, but all of them have basic sewing and handicraft works, English, and computer courses. Three out of four associations offer a production center that offers employment for many girls after training. This training may only prepare women for entry-level job positions. Alfiasaliha women’ association was very specific in its aims, targeting not only their beneficiaries, but opening lectures and workshops to the public. On the other hand, the other three associations target only needy women who receive assistance from the association. 


\section{Chapter Six}

\section{Conclusion}

The second decade of the twentieth century has witnessed the establishment of the modern Saudi state. This establishment took place in a thousand year-old Arabia which had previously been somewhat isolated. Within decades, the discovery of oil has forced change in a relatively short period of time. Of course, family structure was one of the first elements of society to change. Families went from an extended family structure that relied on its members to provide basic needs, to a nuclear family structure that is independent, but relies on formal institutions for basic needs. The woman's role has always been considered primary in running the household, and women always helped in agriculture and grazing livestock cattle. However, moving outside of the protection of the family wasn't easy for women, due to the strong traditions of the Arabian society. Education was the first door opened to women in Saudi Arabia, and religion played a major role. Because social traditions and religion were so mixed together, people could not differentiate between them. Islam came to banish negative behaviors and tradition, and to enhance positive ones, but people's individual and sometimes self-serving interpretations, caused the religion to be misused.

In Saudi families, women have always been respected, but were much better protected in the past. Women in Saudi society have always been protected in such ways, due to vulnerabilities such as a girl's honour. However, it is truly unfair to say that Saudi women did not achieve considerable rights and status, because there is no comparison between women's conditions now and their conditions forty years ago. Naturally, it will take some time, but women will eventually achieve their goals. 
Saudi women have been very wise to balance between their roles as wives and mothers, and maintaining employment or getting an education. In fact, these women have had to carry an extra burden for choosing to pursue better education and employment. No one can understand Saudi society as the Saudi woman herself, because she was the mother who participated in raising every generation, and she knows better how to deal with sensitive issues, knowing when she has to move and when she has to stop.

Now, education is ensured for every woman, and it is common for women to work to participate in the family income. In addition, there are thousands of Saudi women who achieve remarkable success in their educations and at their jobs. For example, it is acceptable now for Saudi women to travel abroad to seek a Ph.D. or Master's degree, and her husband will support her by leaving his job and following her. Thousands of scholarships are guaranteed for Saudi women each year to continue higher education in any university of their choosing.

There are however, still many Saudi women who live in very poor conditions. Losing the male is often the main reason. Until now, there have been large portions of the population of women in Saudi Arabia who are totally dependent on their male partner, or on their father. And many times these women have not sought appropriate jobs or education. Therefore, losing the male supporter for any reason can put these women in immediate distress. These disadvantaged women had to seek an income, or had to find other alternatives, such as a social welfare center, to find financial support.

Social service centers had to satisfy the growing need to support poor women, not only financially, but to provide them with the essential tools to support their families and themselves. However, according to this study, social service centers are 
providing basic services for women, such as financial assistance, educational courses, social guidance, and counselling. Although these services provide basic educational courses, these centers still try to offer the means for women to educate themselves and to find their own sources of income.

The establishment of the first private social service associations in Saudi Arabia, for women and with female members and staffs, was a remarkable achievement and a great success for Saudi women. They were created as a result of a deep belief and determination to claim participation for women in society. The private association was not imposed on women, but was a result of women's own efforts. In other words, the presence and the success of such specialized women's institutes, make a statement for women's abilities and independence from male supervision and authority.

The women's welfare institutes were as a soft movement that opened the door for all kinds of women to participate in society and lead to change. In other word, these welfare institutes not only by providing services but constructing the foundation for change through social services for more expanding of women's role. The idea of welfare institutions came from the idea of justice not only justifying the need of women but also assuring the principle of justice. The contribution of these institutes may seem as a small change in the overall change but these institutes are participating in the gradual change of the society.

This is a descriptive study that describes and explains some of the social services for women in Saudi Arabia. One basic thing, which has been proven by this study, is the availability of specialized programs for women, which have been provided by social services centers. The quality of these programs has not been tested in this study. In fact, it has been shown that most of the social services centers have provided 
similar services for women such as, computer, English, art, and sewing courses. The study also found that both Women's Welfare Society and Afaisaliha Women's Association are targeting women in specific and have mentioned women and girls independently. On the other hand, the Agency of Social Affairs (public agency) had motioned women within the family context.

This study focused on the investigation of social services centers which provide services for women. However, due to many limitations, it was not possible to test hypotheses which might indicate relationships between variables. Future research can be directed at testing hypotheses such as the following:

- There are relationships between development services and improving women’s conditions.

- A new level of recognition of women's needs has affected social policy and programs.

- There are relationships between educational programs and enhancing women's well-being.

It would also be interesting if future research could be conducted in Saudi Arabia, and studies done in an actual social services setting. For example, this study could be conducted in the future in such an actual setting, using surveys and interviewing methods. It is important not only to analyze documentation, but also to use other methods to test results. Future research could also compare social services with other fields, such as education and health, and how they provide services for women in Saudi Arabia.

In the near future, any research on women in Saudi Arabia should be interesting, due to the changes that are continually taking place, especially with the large percent 
of youth population that will support this change. Studying women's issues in a country like Saudi Arabia is not an easy task, due to the contradictions that surround women within the society. The added interest in women's issues in Saudi Arabia has particularly enriched the field of social work, and has provided many avenues within the sociological field in general, for studying subjects relating to women. 


\section{Bibliography}

Albir Association. 2001. Annual Report. Jeddah.

Albir Association Web Site. Retrieved September 8, 2004. (http://www.albir.org).

Alfaisaliha Women’s Charity Association. 2002. Annual Report. Jeddah.

Al-hazzaa, Abdulaziz. 1993. "Scenario Projection for Women in Saudi Arabia: Their Changing Status, Educational and Employment Opportunities by the Year 2010.” Ph.D. dissertation, University of Minnesota, Minnesota.

Almaghlooth, Fahad A. 1992. “A Study of Social Work in Community Development Practice in Saudi Arabia: Implication for Professional Social Work Development.” Unpublished Ph.D. dissertation, University of Pittsburgh, Pittsburgh.

AlMunajjed, M. 1997. Women in Saudi Arabia Today. New York, NY: St Martin’s Press.

Alqabaa, Mendel. 2001. “For an Effective Use of Woman’s National Roles.” Journal of the Ministry of Labor and Social Affairs 7:32.

Alsaif, Abdulmohsen. 1991. "Social Work in Saudi Arabia: The Development of a Profession.” Ph.D. dissertation, Florida State University, Tallahassee.

Alsoghair, Saleh. 1995. “Citizen Participation in Rural Community Development Centers: An Example From Saudi Arabia.” Ph.D. dissertation, Mississippi State University, Mississippi.

Alzahrani, Saeed. 2000. “Alfiasaleha Women’s Charity Association: Twenty-four Years of Charity Work Serving.” Labor and Social Affairs Journal 2:10-11.

Bargawi, Khalid Y. 2002. "Social Work Community Services Provided by Community Development and Social Work Centers.” Unpublished Ph.D. dissertation, Ohio State University, Columbus.

Bush, Irene R and Kathrine M. Kraft. 1998. “The Voices of Welfare Reform.” Public Welfare 56(1).

CIA World Fact Book. Retrieved May 20, 2004 (http://www.cia.gov/cia/publications/factbook/geos/sa.html\#People). 
Colorado State University Writing Center. Retrieved May 4, 2004

(http://writing.colostate.edu/references/research/content/index.cfm).

Dolgoff, Ralph and Donald Feldstein. 2000. Understanding Social Welfare. $5^{\text {th }}$ ed. Needham Heights, MA: Allyn and Bacon.

Evans, Patricia. 1998. “Gender, Poverty, and Women’s Caring.” Pp. 47-68 in Women's Caring: Feminist Perspectives on Social Welfare, edited by Carol T. Baines, Patricia Evans and Sheila M. Neysmith. Oxford Univerdity Press: Canada.

Fleischmann, Ellen L. 1999. “The Other 'Awakening’: The Emergence of Women’s Movements in the Modern Middle East, 1900-1940.” Pp. 89 -137 in Social History of Women and Gender in the Modern Middle East, edited by Margaret L. Meriwether and Judith E. Tucker. CO: Westview Press.

Hallett, Christine. 1996. "Social Policy: Continuities and Change." Pp. 1-14 in Women \& Social Policy: An Introduction, edited by Christine Hallett. Great Britain: T.J. Press.

Johnson, William Jr., Richard P. Rettig, Gregory M. Scott, and Stephen M. Garrison. 2004. The Sociology Student Writer's Manual. $4^{\text {th }}$ ed. Upper Saddle River, NJ: Pearson Education, Inc.

Library of Congress Country Studies. Retrieved May 20, 2004 (http://lcweb2.loc.gov/cgi-bin/query/r?frd/cstdy:@field(DOCID+sa0011).

Midgley, James. 1995. Social Development: The Developmental Perspective in Social Welfare. Thousand Oaks, CA: Sage.

Midgley, James. 1997. Social Welfare in Global Context. Thousand Oaks, CA: Sage.

Ministry of Labor and Social Affairs. 1999. The Establishment and Development of Social and Labor Services in theKingdom of Saudi Arabia. Riyadh: Ministry of Labor and Social Affairs.

Ministry of Labor and Social Affairs. 2003. Social Affairs: Care and Development. Riyadh: Ministry of Labor and Social Affairs.

Papart, Jane. 2002. Gender and Empowerment: New Thoughts, New Approaches. Edited by Vandana Desai and Robert B. Potter. New York: Oxford University Press Inc.

Royal Embassy of Saudi Arabia in Washington D.C. Retrieved May 20, 2004 (http://www.saudiembassy.net/).

Saudi Ministry of Culture \& Information. Retrieved May 20, 2004 (http://www.saudinf.com/). 
The Washington Post Web Site. "International Spotlight: Saudi Arabia.” Retrieved May 20, 2004 (http://www.washingtonpost.com/wpadv/specialsales/spotlight/saudi/art14.html).

Thomas, A. and P. Smith. 2003. Spotlight on Social Research. Pearson Education.

United Nations. 1986. Developmental Social Welfare. New York, NY: United Nations Publication.

United Nations. 2002. Arab Human Development Report. New York, NY: United Nations Publication.

Uthaimeen, Yousef A. 1986. "The Welfare State in Saudi Arabia: Organization, Finance, and Dynamics.” Ph.D. dissertation, The American University, Washington, D.C.

Women’s Welfare Society. 1999. Annual Report. Jeddah. 